\title{
Organic waste reclamation, recycling and re-use in integrated fish farming in the Niger Delta
}

\section{ORIBHABOR, BJ; ANSA, EJ}

\author{
African Regional Aquaculture Centre /Nigerian Institute for Oceanography and Marine Research (ARAC/NIOMR), P.M.B. 5122,
} Port Harcourt, Nigeria.

\begin{abstract}
The purpose of this paper is to create awareness on the significance of integrated fish farming in organic waste reclamation, recycling and re-use. Example of integrated fish farming practiced at a micro-level in the Niger Delta of Nigeria is crop-snailry-poultry (Chicken) - livestock (pig) - cum-fish production. In this system, fish production remains the most important activity. The organic wastes reclaimed, recycled and re-used in this system are: plant matter, chicken and pig excrements; snail, oyster and periwinkle shells, ox blood and bone, fish wastes, palm kernel cake, groundnut cake, pond silt and aquatic fern, Azolla pinnata. Other reclaimable, recyclable and re-usable materials are also discussed in this paper. Integrating organic waste reclamation, recycling and re-use in integrated fish farming with treatment, incineration, landfill and composting will help to drastically reduce waste in both rural and urban areas. @JASEM
\end{abstract}

Waste reclamation implies recovery of a component of waste for use in a manner different from its initial function, re-use denotes multiple use of a given material or product; and recycling consists of recovering from waste the matter of which a product was made and re-introducing it into the production cycle for reproduction of the same item (Ademoroti, 1996). In integrated fish farming, many organic wastes are being reclaimed, recycled and re-used. This system of farming has been proposed as an environmental friendly way of recycling wastes, especially those produced through the cultivation of high trophic level fish species which require the supply of exogenous energy (Buschmann, 2000). Reclamation, recycling and re-use helps to solve the problems of wastes disposal and scarcity of resource materials. Integrated fish farming is a traditional practice and one of the developmental characteristics of aquaculture in China (Hu and Zhou, 1989). In many of the integration processes in Asia and other parts of developing countries, fish production remained as the most important activity. However, commercial pig/chicken/duck production activity has also been accompanied by fish and crop production, mainly by using the animal waste as fish feed and manure for crops respectively (Mukherjee, 1995). In the integrated ecosystem, crops are producers, livestock and fish are consumers, aquatic and soil organisms are decomposers, it is a complete ecosystem (Yang and $\mathrm{Hu}, 1989$ ). Aquaculture has recycled animal wastes as fertilizer for centuries, with the aim of boosting pond productivity of plants and animals (Velasquez, 1980; Oladosu et al, 1990). Animal wastes apart from their use for fertilization, have many qualities which make them valuable (Nash et al, 1980). They contain protein, amino acids and other nutrients and thus can be processed into animal feed and feedstuffs (useful materials which can be reclaimed and re-used).

There is likely to be a significant increase in agricultural wastes globally if developing countries continue to intensify farming systems (UNEP, 1992). In developing countries, salvaging of secondary raw materials from tips is an important source of income for some people and in some cities, e.g. Medellin, Colombia, it is an important source of raw materials for local industry. Small-scale projects for composting and biogas generation from house hold and agricultural waste have been set up in many rural communities. These approaches to managing wastes are not wide-spread or effectively organized, but may offer practical and cost effective solutions to the problems of waste disposal faced in the developing countries. Internationally, there is increasing awareness for treatment, incineration, landfill and composting as ways of solving problems of solid wastes. The level of awareness for integrated fish farming in combating the problems of organic household, industrial and agricultural wastes in the Niger Delta is poor. The purpose of this paper is therefore to create awareness on the significance of integrated fish farming in organic wastes reclamation, recycling and re-use.

\section{MATERIALS AND METHODS}

Data were generated from field observation, experimentation, review of literature, and personal interviews in three states in the Niger Delta namely Bayelsa, Rivers and Akwa Ibom. 


\section{RESULTS AND DISCUSSION}

Lay-out of integrated fish farming practiced at microlevel in the Niger Delta In the Niger Delta of Nigeria, it has been observed that micro-level practice of integrated fish farming exists with crop-snailrypoultry (chicken) - livestock (pig) - cum - fish production system. In this system, fish production remains the most important activity. The cultivated crops in the system are pineapple (Ananas sp.), plantain (Musa sp.), paw-paw (Carica papaya), maize (Zea mays), pumpkin (Telfairia occidentalis) and waterleaf (Talinum triangulare). The species of snail reared are Archachatina marginata and Achatina achatina. The poultry production consists of egg laying birds and of different exotic broilers; while the livestock consists primarily of different exotic and local pig breeds. The fish consists of fry, fingerling, table size fish and broodstock of Clarias gariepinus, (African catfish), Heterobranchus bidorsalis, Heterobranchus longifilis (mud catfish), hybrid catfish (Clarias $x$ Heterobranchus), Oreochromis niloticus, Tilapia zilli, Heterotis niloticus, Ophiocephalus (Channa) (snake head fish) and Gymnarchus niloticus.

The usual practice is that the crop unit, snailry and pig breeding pens are sited on a portion of land in the farm, off the fish ponds. Pigsty for grow-out or fattening of pigs are constructed on pond dykes; and the poultry houses are constructed over production ponds in a vertically integrated system.

Reclamation, recycling and re-use of organic wastes in the Niger Delta: Organic wastes currently reclaimed, recycled and re-used at micro-level in the Niger Delta are: plant matter such as plantain leaves, ripe plantain, unripe and ripe fruit and leaves of pawpaw; wet chaff from fermented, milled or ground maize. Other wastes are chicken and pig excrement; snail, oyster and periwinkle shell; ox-blood, ox-bone, fish waste, brewers waste, palm kernel cake (byproduct of oil processing), groundnut cake (byproduct of groundnut oil processing), pond silt and aquatic fern, Azolla pinnata. The plant matter is used as feed for the snails; while excrements/ waste from the snails, chicken and pigs are used as manure for crops such as pumpkin and waterleaf.

Chicken and pig excrements are used as food and manure in fish ponds. They are either used in the wet form or dry form. In tropical fish farming, organic domestic or animal husbandry wastes serve both as food and fertilizer. The microbial decomposition of duck, goose, chicken, pig, goat and ox excreta, enriches the water with nutrients which contribute to

Oribhabor, BJ; Ansa, EJ nutrients for producing phytoplankton, zooplankton and, finally fish (Simoens, 1995). Due to the short digestive tract of poultry, $80 \%$ of chicken manure represents undigested feed-stuff (Chen, 1981) with as high as $20-30 \%$ total protein (Pudadera et al, 1986). Hence, under the integrated poultry-fish farming system, both the Tilapia and the African mudfish (stocked in polyculture), have two additional sources of feed apart from the higher rate of plankton bloom in the pond (Schroeder, 1980). Uneaten chicken feed which could have passed for waste and fresh chicken droppings that are consumed directly by both fish species are added advantages in terms of feed sources (Pudadera et al, 1986 and Barash et al, 1982). Oladosu et al, 1990 observed in their study that the performance of Clarias gariepinus in polyculture with Oreochromis niloticus under integrated poultrycum-fish farming system is best with the application of supplemented feeding. Table 1 shows composition of fish diet used. Chicken wastes are considered to be more valuable in quite a few countries for vegetable farming (Little and Muir 1982). Chicken manure is the best among the commonly used organic fertilizers and is commonly used in fish farms practising polyculture, in China, Philippines, India, Israel and other countries. Processed poultry manure can be used to feed pigs and pig manure can be used to fertilize fish ponds (Chen, 1981). Fig 1 shows comprehensive chicken manure utilization.

Table 1: Composition of Nigerian Institute for Oceanography and Marine Research (NIOMR) fish diet

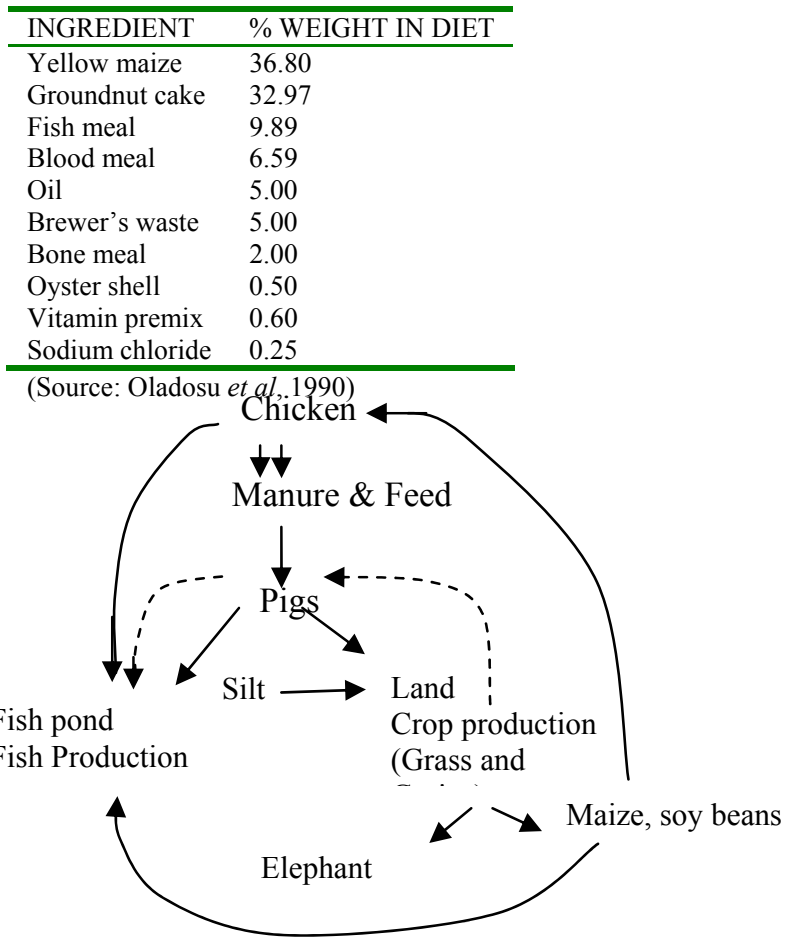

Fig 1: Comprehensive chicken manure utilization (Source: Adapted from NACA, 1989) 
Chicken manure, pig manure and brewers waste are used as substrates for production of housefly (Musca domestica) maggots which are in turn used as fish feed, or in making supplementary fish feed (Fig 2 and 3)

Chicken Manure

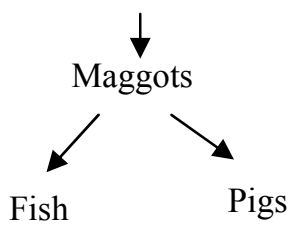

Fig 2: Utilization of chicken manure in maggot production

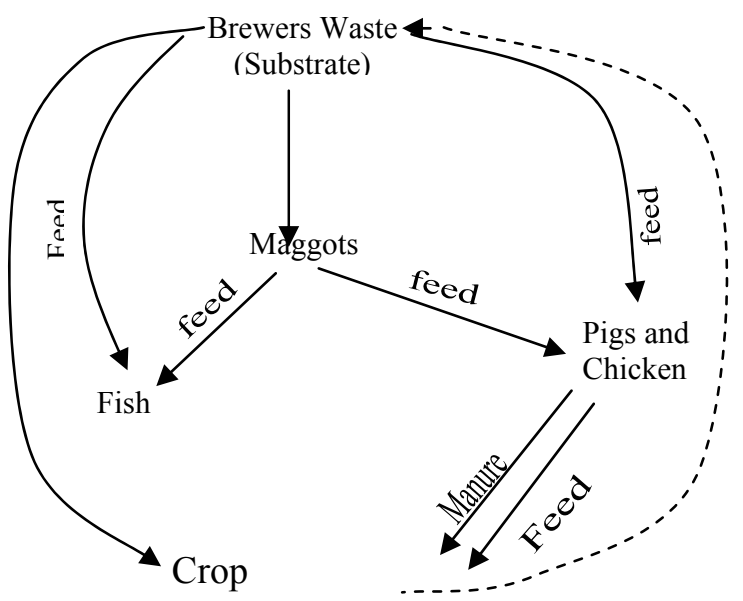

Pig manure could be used in the form of pig-on-litter system which is a dry system that is basically an in situ fermentation or composting process using special bedding comprised of a mixture of saw dust and bacterial products to absorb, decompose and stabilize the pig waste as and when it is produced. The dried mass can be used to form pellets for fish and ruminant feeding (Mukherjee, 1995). Ansa and Jiya (2002) discovered that although the specific growth rate (SGR) values of Tilapia fed the formulated diet (control) (combination of ox-blood and wheat bran) were high, the SGR $(0.81 \%$ /day) for pig manure pond was even higher and an indication that Tilapia can achieve reasonable growth under fish-cum-pig integration without addition of supplementary feeds (Table 2).

Fig 3: Comprehensive utilization of brewer's waste

Table 2: Growth rates and yield of Oreochromis niloticus in pig manure and formulated diet ponds

\begin{tabular}{|l|l|l|l|l|l|}
\hline Growth parameters & A & B & C & D & \\
\hline Average weight in stocking (g) & 6.26 & 7.53 & 8.00 & 8.35 & \\
\hline Daily grass rate (g/day) & 0.25 & 0.22 & 0.27 & 0.30 & \\
\hline Specific growth rate (\%/day) & 0.81 & 0.67 & 0.76 & 0.79 & \\
\hline Average weight in 70days & 3.46 & 22.61 & 26.9 & 29.68 & \\
\hline Yield in 70 days (Kg/ha) & 246 & 237 & 287 & 318 & \\
\hline
\end{tabular}

Ponds $A$ and $B=$ pig manure as feed source; Ponds $C$ and $D=$ formulated fish diet (Combination of ox-blood and wheat bran) (Source: Ansa and Jiya, 2002)

Fish wastes (heads, bones, guts etc is chopped up and fed as supplement to pigs. Pig-breeding benefits from various by-products of fish farming such as frogs and macrophytes (Randriamiarana et al, 1985).

Cow blood (protein source) and bone meal (calcium source) are used respectively for production of fish and pig supplementary feeds. Other organic wastes used in making such supplementary feeds are: brewers waste, palm kernel cake, groundnut cake, toad meal, tadpolemeal crabmeal, oyster and snail shells (Ayinla et al, 1992, Idoniboye et al, 1993 and Bekibele et al, 1995). Pond silt is used as manure for crops. An appropriate amount of pond silt is beneficial to the pond as a fertilizer; however, an excess amount of silt is detrimental to water quality (Huazh and Baotong, 1989). As a fertilizer, silt increases the thickness of the cultivation layer, improves the soils particle structure, strengthens its ability to absorb nitrogen $(\mathrm{N})$, phosphorus $(\mathrm{P})$ and potassium (K) and improves the soils capacity to hold water. It is also a slow acting fertilizer, which is beneficial to late crops (Huazh and Baotong, 1989). 
Perwinkle shells are used in road construction, making concretes and filling of flooded grounds. Oyster shells are used in the production of calcium carbides, lime, fertilizer and cement. House wives use the ashes of shells as an abrasive which is tough on stains and can be used to polish metal wares (Ansa and Bashir, 2003).

Aquatic fern, Azolla pinnata has been used as an experimental feed for Oreochromis niloticus. Abioye et al, (1993) recorded better growth performance in treatment containing Azolla pinnata meal. The best response was observed in the $20 \%$ replacement level, thereby suggesting an optimum replacement (Table 3). Azolla grown in ponds can be given as feed to fish, chickens, ducks, pigs and rabbits in fresh, dried, ensiled or pellet form (Van Hove and Ruelle, 1989).

Table 3: Composition of experimental diets on Azolla pinnata as a possible replacement of palm kernel cake (at $20 \%$ replacement) in the diet of Oreochromis niloticus

\begin{tabular}{ll}
\hline MATERIALS & $20 \%$ REPLACEMENT $(\mathrm{G})$ \\
\hline Maize & 32.50 \\
Palm kernel cake & 30.00 \\
Dried azolla pinnata & 7.50 \\
Soya beans & 10.00 \\
Bone meal & 3.75 \\
Premix & 1.00 \\
Salt & 0.40 \\
Rice bran & 9.00 \\
Palm oil & 2.00 \\
Starch & 4.00 \\
\hline
\end{tabular}

(Source: Abioye et al, 1993)

Other aspects of organic waste reclamation, recycling and re-use

Other reclaimable, recyclable and re-useable waste materials are: household waste, scraps from slaughter houses, feather, cow manure, treated sewage, pig hairs, papers and biogas waste materials. Fish can be fed with scraps from slaughter houses, brewing drafts, household waste, rice bran, fresh or cooked manioc, lima beans or potatoes (Randriamiarana, 1995). Feather meal is a dietary ingredient in poultry rations. The so called hydrolyzed feather meal is really a misnomer. It is at best a slight hydrolyzed product produced by cooking feathers in the presence of calcium hydroxide to increase its digestibility. Feather meal has been evaluated in both fresh and salt water fish species. Good results have been reported when it is used in catfish diets at 15 percent inclusion level (Spinelli, 1978). Cow manure serves as fish feed and fertilizer. Fish farming using cow manure has long been practiced in China. Integrating fish and cow farming reduces the necessity to purchase fertilizer and fish feeds, and increases the income generated by the fish farmer. Cows are ruminants and because of the repeated grinding and digestive decomposition catalyzed by the many micro-organisms in the rumen, cow manure is very fine. Among all livestock excreta, cow excreta is the most abundant and, in terms of availability, the most reliable.

Treated sewage is used to grow phytoplankton. The shellfish then removes the phytoplankton from the water. Solid wastes produced by shellfish and uneaten phytoplankton support dense populations of small invertebrates (amphipods, worms etc). These can serve as food for a secondary crop of lobster or flounder. Culture of molluscs and seaweeds may in certain cases counteract processes of nutrient and organic enrichment in eutrophic waters. Conversely, productivity of oligotrophic water may be enhanced due to the nutrient and organic wastes released from aquaculture farms (Barg, 1992). Considering seaweeds as renewable biological nutrient scrubbers allows an understanding of one of their fundamental roles in coastal ecosystems and validates their use in integrated aquaculture systems (Chopin et al, 2001). Pig hairs are used as brush bristles. The major raw materials needed for biogas production is organic matter such as food waste, human and animal excreta, dead leaves and plants. In this process, about $90 \%$ of methane $\left(\mathrm{CH}_{4}\right)$ and $30 \%$ of carbon dioxide are produced. Pig-fish system can be modified to a pig biogas-fish system, as practiced by Maya farms in the Philippines (FIG 4). The farm has developed a biogas production system, which is the source of energy to run waste pumps, feed mixers, generators and some electrical equipment in the farm (Mukherjee, 1995). Residues of anaerobic fermentation to produce biogas can be used to fertilize fish ponds.

Problems and solutions associated with organic waste reclamation, recycling and re-use. The problems related to utilizing wastes could be grouped into environmental, health, aesthetic, religious taboo and lack of processing technology. In some countries of Asia (Taiwan, Hong Kong, Singapore and Malaysia) environmental laws are becoming rigid. Without treatment of animal or industrial wastes, it could be difficult in future to use them as pond manure or animal/fish feed. Lack of effluent treatment causes pollution of receiving ponds/streams, development of sludge banks in the ponds or vicinity of waste discharge, eutrophication and spread of disease. These problems could be avoided by control and careful application of wastes into ponds/streams, inserting the wastes into porous bags before application in different areas of the ponds, and regular checks of sampled fish from the pond and control measures to prevent incidence and spread of disease. 
Problems pertaining to pig-fish integrated systems include heavy odour and religious taboo. The odour problem could be overcome by any of the following methods (Arboleda, 1992):

- Keeping provision of controlled but continuously flowing water into the pond by trapping water from a nearby pond or canal.

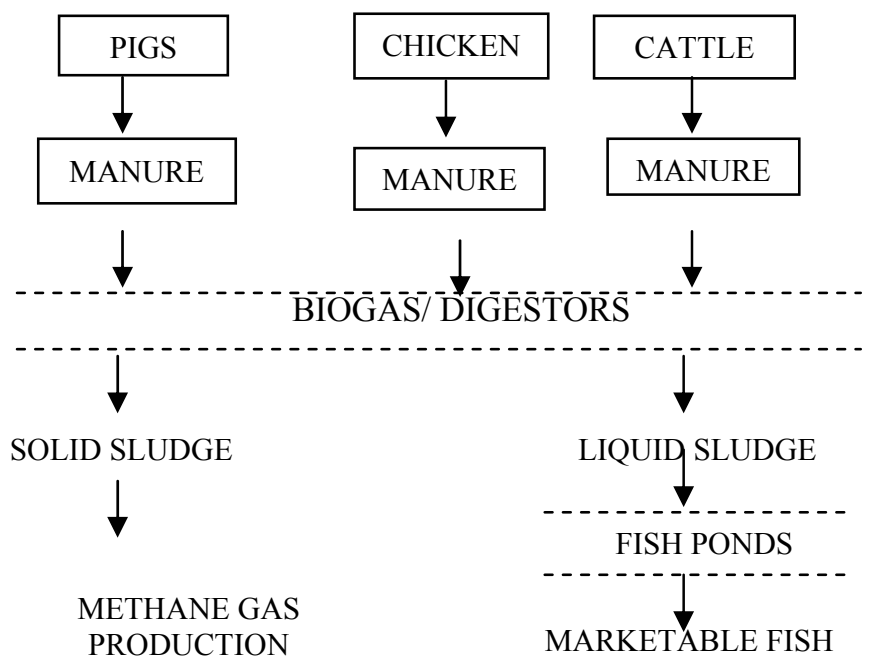

FIG 4: Integrated livestock-biogas-fish production system: Maya farms model

(Source: Mukherjee, 1995)

Research has shown that fish cultured under the integrated chicken-fish farming system are fit for human consumption. According to Pudadera et al, (1986), pathological examination of such fish prior to harvest showed that they are not infected by any micro-organism that could render them unfit for human consumption. Also, Yingxue et al, 1986 observed that the nutrient content of the fish fed on pelleted fish diet is not better than for fish fed on chicken manure. There are many officially approved plant and animal by-products in the feed industry, but most of them are not in use because of lack of processing technology. There is therefore the need for advancement in the technology of waste processing for animal feed and manure. While the world food production could grow significantly to feed the ever growing population, the loss of soil fertility, erosion of land, degradation of rangelands, increased industrial activity in the existing agriculture land, water logging and salinization of agriculture lands will continue to hamper such increased productivity. In order to overcome these problems, integrated crop- livestock-fish farming has been suggested as one of the alternatives to large scale monoculture farming. Many livestock specialists and aquaculturists believe that integrated farming is a type of eco-farming in which the maximum utilization of resources including wastes is
Transfer of the male fish from the manure ponds to non-manure ponds a month before their marketing age: this operation, though expensive, removes the objectionable odour and taste from the fish. proportionately related to minimum damage of the environment (Mukherjee, 1995).

In the Niger Delta of Nigeria, integrated agroaquaculture is being practiced at a micro-level. Acquisition of new technologies for intensification of organic waste conversion to feed and fertilizer will improve the economic status of farmers, reduce unemployment and finally, reduce environmental problems caused by household, agricultural and industrial organic wastes. The increase in fish production which wastes facilitate is very considerable in countries where rural areas are not yet living in a sufficiently monetized economy for fish farmers to engage profitably in feeding techniques based on purchasing feeds (Symoens, 1995). Natural food organisms cultured in fishponds using organic manure could completely replace pelleted feeds. Fertilizing with animal manure will not change the quality of fish. Fish-cum-cow integration will not only generate income for the farmer but also supply fish and milk to the market, decrease expenditures, reduce unemployment and save energy (NACA, 1989). Integrating organic waste reclamation, recycling and re-use in integrated fish farming with treatment, incineration, landfill and composting will help to drastically reduce rural and urban organic wastes generation problems. 


\section{REFERENCES}

Abioye, OM; Adeyemo, AA; Ayinla, OA; Bekibele, DO; Esiobu, D (1993). Azolla pinnata as a possible replacement of palm kernel cake in the diet of Oreochromis niloticus. NIOMR Tech. Pap. No. 94. 10pp.

Ademoroti, CMA (1996). Environmental Chemistry and Toxicology. Floudex press Ltd., Ibadan, Nigeria. 217pp.

Ansa, EJ; Jiya, J (2002). Effect of pig manure on the growth of Oreochromis niloticus under integrated fish-cum-pig farming System. Journal of Aquatic Sciences, 17 (2): 85-87

Ansa, EJ; Bashir, RM (2003). Fisheries and culture potentials of the mangrove oyster (Crassostrea gasar) in Nigeria. African Journal of interdisciplinary studies (In press).

Arboleda, CR (1992). Integrated livestock-fish production system in the Philippines; In Mukherjee, T.K. et al. (eds). Proceedings FAC/IPT workshop on integrated livestock-fish production systems (Kuala, Lumpur, 16-20 December, 1991). Institute of Advanced Studies, University of Malaysia, Kuala Lumpur, pp.95-100.

Ayinla, OA; Kayode, O; Idoniboye-Obu, TIE; Oresegun, A; Adindu, VE (1992). Utilization of tadpole meal in the diet of Heterobranchus, bidorsalis (Geoffry St. Hillaire, 1809). NIOMR Tech. Pap. 80, 11pp.

Barash, H; Planik, I; and Moar, R (1982). Integrated duck and fish farming- experimental results. Agriculture Vol. 27 No 2. pp 129.

Barg, UC (1992). Guidelines for the promotion of environmental management of coastal aquaculture development . FAO fisheries Technical paper 328. 122pp.

Bekibele, DO; Ayinla, OA; Saidu, AA (1995). The Effect of replacing fish meal (Tuna waste) with graded levels of toad meal in diet for Clarias gariepinus fingerlings (Burchell 1822). NIOMR Tech. Pap. 99, 11pp.

Buschmann, AH (2000). Integrated cultivation of salmon and seaweed: Productive, Environmental and Economic issues. Aquaculture Canada 2000 Abstracts.
Chen, Y (1981). Chicken farming in integrated fish farming vol. 11 pp 4 - 30 . Regional Aquaculture Lead Center Wuxi, China.

Chopin, T; Yarish C; Sharp, G (2000). Nutrients, Fish and seaweeds;- Integrated "fed" and "Extractive" Aquaculture for bioremediation of coastal nitrification. Aquaculture Canada 2000 Abstracts.

Hu, B; Zhou, E (1989). Review on development of integrated fish farming in China. Selected papers of freshwater fisheries research, Asian-Pacific Regional Research and Training centre for integrated fish farming, p.89-110.

Huazh, Y; Baotong, H (1989). Introduction of Chinese integrated fish farming and some major models. In: NACA Technical manual 7, Integrated Fish Farming in China, A world food day 1989 publication of the Network of Aquaculture Centres in Asia and the Pacific, Bangkok, Thailand, pp. 150-191.

Idoniboye-Obu, TIE; Ayinla, OA; Alfred-Ockiya, JF (1993). Utilizing Crab meal as partial substitute for dried brewer's yeast in a practical diet for Tilapia guineensis. Journal of Aquatic Sciences 8:11-21.

Little, D; Muir, J (1987). A Guide to Integrated Warm water Aquaculture. Inst. of aquaculture, University of Stirling.

Mukherjee, TK (1995). Integrated crop-livestockFish production systems for maximizing productivity and economic efficiency of small holders farms. In: Symoens, JJ; Micha, JC. Seminar proceedings RAOS/GA/FAO on the Management of integrated freshwater Agropiscicultural Ecosystems in Tropical Areas (Brussels, 16-19 May, 1994) pp. 121-143.

NACA (1989). Integrated Fish Farming in China, A World Food Day Publication of the Network of Aquaculture Centres in Asia and the Pacific, Bangkok, Thailand. 278pp.

Nash, E; Collins, FH; Brown, J; Carol, M (1980). A Theoretical comparison of waste treatment processing ponds and fish product ponds receiving animal wastes. Pp. 87-97. In: Pullins, RSV; ZH, Shehadeh (eds). Integrated Agriculture-Aquaculture farming system ICLARM-SEARCH Manila, Philippines. 
Qladosu, GA; Ayinla, OA; Onuoha, GC; Needom, JG (1990). Performance of Clarias gariepinus in polyculture with Oreochromis niloticus under the integrated broiler chicken fish farming. NIOMR Tech. Pap. No. 65. 22pp.

Pudadera, BJJ; Corre, KC; Coniza, E; Taleon, GA (1986). Integrated farming of broiler Chicken with fish and shrimp in brackish water ponds, pp. 141-144. In: Macleen, JL; Dion, LB; Hosillos, LV (eds.). The First Asian Fisheries Forum. Asian Fisheries Society, Manila, Philippines.

Randriamiarana, H; Rabelahatra, A; Jansen, J (1995). Rice/fish farming in Madagascar. The present situation and future prospects and constraints. In: Symoens, JJ; JC Micha, Seminar Proceedings

RAOS/ GA/FAO on: The management of freshwater Agro-pisciculture Ecosystems in Tropical Areas (Brussels, 16-19 May, 1994) pp. 353-371.

Schroeder, GL (1980). Fish farming in manure loaded ponds. pp. 73-86 In: Pullins, RSV; Ziad, $\mathrm{H}$; Schehadeh (eds). Integrated AgricultureAquaculture farming system. ICLARM SEARCH Manila, Philippines

Spinelli, J (1998). Unconventional feed ingredients for fish feed In ADCP/REP/80/11. Fish feed technology. Lectures presented at the FAO, UNDP Training course in fish feed technology, held at the College of Fisheries, University of Washington. Seattle, Washington, 9 October -15 December 1998. pp-187-214
Symoens, JJ (1989). Sustainable use of wetlands. In: Symoens, JJ; Micha, TC. Seminar proceedings RAOS/CTA/FAO. In: The Management of Freshwaters Agro- piscicultrual system in Tropical Areas (Brussels, 16-19May, 1994) pp. 87-107.

UNEP (1988). Industry and Environment, Published by the United Nations Environment Programme, October/November 1988 vol. 11, No 4 UNEP. Industry and Environment Office France 21pp.

Van Hove, V. and Ruelle, JE (1989). Azolla, sesemplis multiples, son interest en AfriqueFAO.

Velasquez, CC (1980). Health constraints to integrated animal-fish farming in the Philippines, pp-103-11 In: Pullins, RSV; Ziad, H; Shehadeh (eds). Integrated Agriculture- Aquaculture farming system. ICLARM- SEARCH, Manila, Philippines

Yingzue, F; Xianzhen, G; Jikun, W, Xiuzheng, F; Zhinyna, L (1986). Effect of different animal manures in fish farming, pp. 117-120. In: Maclean, JL; Dixon, LB; Hosillos, LV (eds). First Asian Fisheries Forum. The Asian Fisheries Society, Manila, Philippines. 